\title{
Growth, phenological and yield responses of a bambara groundnut (Vigna subterranea L. Verdc) landrace to imposed water stress: II. Rain shelter conditions
}

\author{
T Mabhaudhi ${ }^{*}$, AT Modi ${ }^{1}$ and YG Beletse ${ }^{2}$ \\ 'Crop Science, School of Agricultural, Earth \& Environmental Sciences, University of KwaZulu-Natal, Private Bag X01, \\ Scottsville 3209, Pietermaritzburg, South Africa \\ ${ }^{2}$ Agricultural Research Council-Roodeplaat, Vegetable and Ornamental Plant Institute, (VOPI), Private Bag X293, Pretoria 0001, South Africa
}

\section{ABSTRACT}

\begin{abstract}
Bambara groundnut is a protein-rich legume, with food-security potential. Effects of irrigation levels and seed coat colour on growth, development, yield and water-use efficiency of local bambara groundnut landrace selections were evaluated under a rain shelter. Emergence was slow, although variation was indicated between landraces. Limited water availability was shown to lower stomatal conductance, although chlorophyll content index was shown to be unaffected. Additionally, growth indices of plant height, leaf number and leaf area index were shown to be lower in response to decreasing water availability. Furthermore, landraces generally flowered and matured earlier while also demonstrating higher water-use efficiency at lower water availability. Seed yield was lower under limited water availability resulting from lower pod mass and pod number. Drought tolerance in bambara groundnut landraces was achieved by reduced canopy size, early flowering and maturity, and maintaining high water use efficiency under stress. 'Brown' and 'Red' landraces responded to water stress better than the 'Light-brown' landrace, suggesting an effect of seed colour on possible drought tolerance.
\end{abstract}

Keywords: bambara groundnut landrace, growth, phenolology, water use efficiency, yield

\section{INTRODUCTION}

South Africa is a water-scarce country (IWMI, 1996; Republic of South Africa National Water Act, 1998; DWAF, 2004) due to a limited amount of water resources combined with low and uneven annual rainfall (Laker, 2007), which often results in drought. The marginal nature of most of South Africa's agricultural land, and the effects of expected climate change (Hassan, 2006), challenge the existence of major crops and their ability to ensure food security in the future. Neglected underutilised species (NUS) have been reported to have possibly evolved to tolerate harsh environments, including drought stress, and have been touted as possible future (food security) crops. Bambara groundnut (Vigna subterranea (L.) Verdc), locally known as Izindlubu in isiZulu, is one such indigenous legume with potential to contribute nutritional and food security in marginal areas of agricultural production.

Bambara groundnut is an African indigenous legume that has been cultivated for centuries in sub-Saharan Africa, mainly the semi-arid regions, and has in the past contributed to food security (Swanevelder, 1998; FAO, 2001; Azam-Ali et al., 2001; Mwale et al., 2007). Traditionally, it was cultivated in extreme, tropical environments by small-scale farmers without access to irrigation and/or fertilisers and with little guidance on improved practices. It is mainly grown by women for the sustenance of their families (Mukurumbira, 1985; Mwale et al., 2007). It has been reported to contain $17-25 \%$ protein, $42-65 \%$ carbohydrate and 6\% lipid (Aykroyd and Doughty, 1982; Linnemann and Azam-Ali, 1993; Mwale et al., 2007). However,

\footnotetext{
To whom all correspondence should be addressed.

iㅛㄹ +2733 260 5442; fax: +27 332606094 ;

e-mail: tmabhaudhi@gmail.com

Received 14 May 2012; accepted in revised form 25 March 2013.
}

germplasm improvement and management practices have mainly relied on local experience and resources (indigenous knowledge) (Mukurumbira, 1985). Consequently, the crop remains underutilised and is still mainly cultivated from landraces of which very little is known about their growth, yield and water-use responses under water stress conditions.

There is hardly any report in literature describing wateruse efficiency of bambara groundnut. The growth responses of bambara groundnut to water stress have been described in several instances, using growth indices such as plant height, leaf area index and total dry matter (Collinson et al., 1996, 1997, 1999; Mwale et al., 2007; Vurayai et al., 2011a, 2011b; Mabhaudhi and Modi, 2013). However, most of this research has been done under controlled environments (Sesay et al., 2010) and field conditions (Mabhaudhi and Modi, 2013) where quantifying water was not the major objective. Water use efficiency has often been equated to high yield potential under optimum and stressful conditions (Blum, 2005). Reduced plant canopy size and maturity are often associated with increased water use efficiency and better drought tolerance in plants although literature has shown that there may be yield penalties; however, little is currently known of this relationship in local bambara groundnut landraces. Therefore, the objective of the current study was to evaluate growth, development, yield and water-use efficiency of local bambara groundnut landraces, characterised according to seed coat colour, to water stress under rain shelter conditions.

\section{EXPERIMENTAL}

\section{Plant material}

Fresh seeds of local bambara groundnut landraces were collected from subsistence farmers in Jozini $\left(27^{\circ} 26^{\prime} \mathrm{S} ; 32^{\circ} 4^{\prime} \mathrm{E}\right)$, 
northern KwaZulu-Natal, South Africa, in 2010. The same seed lot was used for both seasons during which the trials were conducted. Seeds were characterised according to seed coat colour and sorted into 3 distinct seed coat colours: 'Red', 'Brown' and 'Light brown'. Seed characterisation according to seed colour was based on the hypothesis that dark-coloured seeds tend to be more vigorous than light-coloured seeds and may thus be more drought tolerant compared with light-coloured seeds (Mabhaudhi and Modi, 2010, 2011; Mbatha and Modi, 2010; Zulu and Modi, 2010).

\section{Site descriptions}

Trials were planted at Roodeplaat, Pretoria $\left(25^{\circ} 60^{\prime} \mathrm{S} ; 28^{\circ} 35^{\prime} \mathrm{E}\right)$ during the summer seasons of 2010/11 and 2011/12. Soils in the rain shelters were classified as loamy sand (USDA taxonomic system). Soil physical characteristics were used to generate parameters for amount of water available at field capacity (FC), permanent wilting point (PWP), and saturation (SAT), as well as the saturated hydraulic conductivity, using the Soil Water Characteristics Hydraulic Properties Calculator (Version 6.02.74, USDA Agricultural Research Services). Daily maximum and minimum temperature averages are $28.5^{\circ} \mathrm{C}$ and $15^{\circ} \mathrm{C}$ in summer (November - April) (Agricultural Research Council - Institute for Soil, Climate and Weather). Rainfall was excluded since the rain shelters are designed to close when rainfall starts.

\section{Experimental design}

The experimental design was a factorial experiment arranged in a completely randomised block design; individual plot size in the rain shelter was $6 \mathrm{~m}^{2}$, with plant spacing of $0.3 \mathrm{mx}$ $0.3 \mathrm{~m}$. There were 2 factors: irrigation level and seed colour, replicated 4 times. During the 2010/11 season, only 2 seed colours, 'Brown' and 'Red', were used in the rain shelter experiments. However, in the subsequent season, 2011/12, all three colours ('Brown', 'Red' and 'Light-brown') were used. There were 3 irrigation levels: $30 \%, 60 \%$ and $100 \% \mathrm{ET}_{\mathrm{a}}$.

\section{Irrigation}

Drip irrigation was used to apply water in the rain shelter. The system consisted of a pump, filters, solenoid valves, water meters, control box, online drippers, $200 \ell$ JOJO tank, main line, sub-main lines and laterals. The system was designed to allow for a maximum operating pressure of $200 \mathrm{kPa}$ with average discharge of $2 \mathrm{l} \cdot \mathrm{h}^{-1} \cdot$ emitter-1. Drip lines were spaced according to the plant spacing $(0.3 \mathrm{~m} \times 0.3 \mathrm{~m})$. A black $200 \mu \mathrm{m}$ thick polyethylene sheet was trenched at a depth of $1 \mathrm{~m}$ to separate the plots in order to prevent water seepage and lateral movement of water between plots. Irrigation scheduling was based on reference evapotranspiration $\left(\mathrm{ET}_{\mathrm{o}}\right)$ and a crop factor $\left(K_{c}\right)$.

\section{Data collection}

\section{Plant measurements}

Parameters determined weekly were emergence (up to 35 days after planting (DAP)), plant height, leaf number, leaf area index (LAI), stomatal conductance (SC), chlorophyll content (CC) and days to flowering (DTF). At the end of the season, biomass and yield were determined. Whereas data for growth parameters were collected weekly from 35DAP, destructive sampling was performed biweekly to determine dry mass. Leaf area index was measured using the LAI2200 Canopy Analyser (Li-Cor, USA and Canada). Stomatal conductance was measured using a steady state leaf porometer (Model SC-1, Decagon Devices, USA). Chlorophyll content was measured using a chlorophyll content meter (CCM-200 PLUS, Opti-Sciences, USA); CC data were only measured during the 2011/12 season.

\section{Soil water content (SWC)}

During the 2010/11 season, a neutron water meter was used to determine SWC at soil depths of 20, 40,60, 80 and $100 \mathrm{~cm}$, at weekly intervals. Wet and dry spot readings were determined, together with their corresponding volumetric water contents, in order to obtain a best-fit regression equation (Campbell and Mulla, 1990). The equation was then used to develop a spreadsheet for the conversion of neutron probe readings to corresponding volumetric SWC readings. During the 2011/12 season, ML-2X Theta Probes connected to a DL-2 data logger (Delta-T Devices, UK) were used to monitor SWC in the rain shelters at varying depths. The frequency of data collection for SWC using the Theta probes was every $4 \mathrm{~h}$.

\section{Water-use efficiency (WUE)}

Water use efficiency for the crop was determined as follows:

$$
\begin{aligned}
& \text { WUE }=\frac{\text { Biomass }}{\mathrm{ET}_{\mathrm{a}}} \\
& \text { WUE }=\text { water use efficiency, and } \\
& \mathrm{ET}_{\mathrm{a}}=\text { crop evapotranspiration or water use. }
\end{aligned}
$$$$
\text { where: }
$$

\section{Agronomic practices}

Prior to planting, soil samples were obtained from the rain shelter for determination of soil fertility and texture. Based on soil fertility results, an organic fertiliser, Gromor Accelerator ${ }^{\circledR}$ was applied at planting to meet crop nutritional requirements (Swanevelder, 1998). Routine weeding and ridging were done by hand.

\section{Data analysis}

Analysis of variance (ANOVA) was used to statistically analyse data using GenStat ${ }^{\circledR}$ (Version 14, VSN International, UK). Least significant difference (LSD) was used to separate means at the $5 \%$ level of significance.

\section{RESULTS AND DISCUSSION}

\section{Crop establishment}

During the 2010/11 season, results of emergence showed significant differences $(P<0.05)$ between the 'Red' and 'Brown' landraces, with 'Red' emerging better than 'Brown' (data not shown). During the 2011/12 season, results showed highly significant differences $(P<0.001)$ between landraces, with 'Brown' and 'Red' having higher and faster emergence compared with the 'Light-brown' landrace (Fig. 1). These results suggest a possible effect of seed colour on vigour. Overall, for both seasons, time to $90 \%$ emergence was generally 28 days after planting, indicating that bambara groundnut landraces are slow to establish, as reported by Sinefu (2011) and Mabhaudhi and Modi (2013). Successful crop establishment is critical under water limited conditions. Blum (2009) reported that during crop establishment a significant amount of total available water 


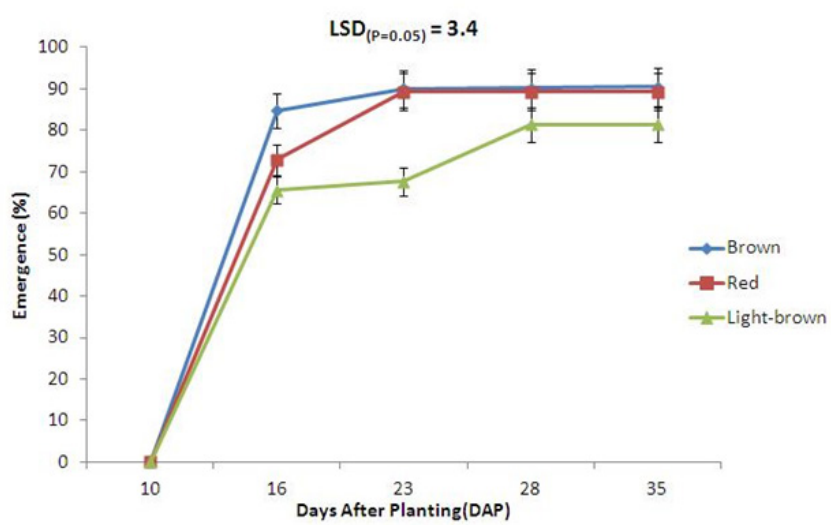

Figure 1

Emergence of bambara groundnut landraces ('Brown', 'Red' and 'Light brown') grown under rain shelter conditions during 2011/12 planting season

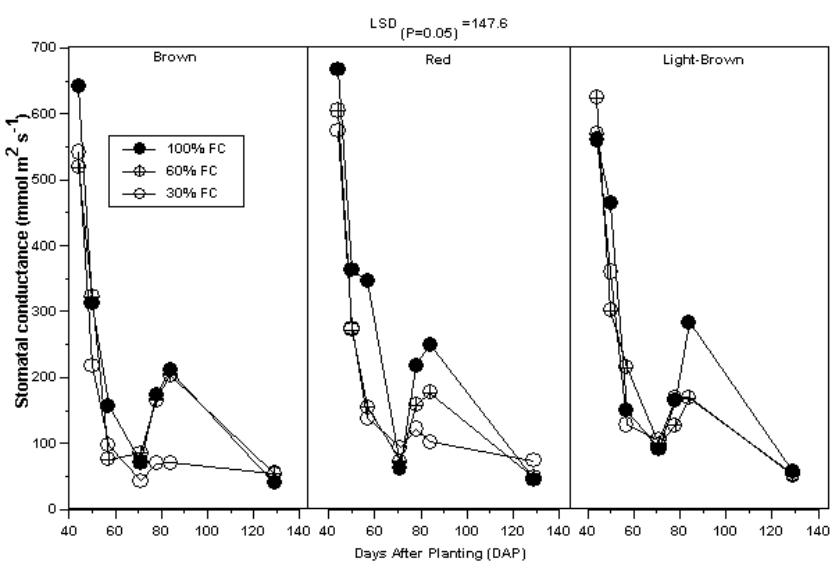

Figure 2

Stomatal conductance $\left(\mathrm{mmol} \mathrm{m} \mathrm{m}^{-2} \mathrm{~s}^{-1}\right)$ of bambara groundnut landraces ('Brown', 'Red' and 'Light brown') grown under a rain shelter during the 2011/12 planting season

is lost through soil evaporation not transpiration. Therefore, a significant amount of water is probably lost to soil evaporation due to slow establishment in bambara groundnut. Researchers in Australia, working on wheat, found that about $40 \%$ of total available water was lost to soil evaporation at the establishment stage (French and Schultz, 1984; Siddique et al., 1990). Vigorous seedling growth is thus essential in establishing canopy cover and reducing water losses to evaporation (Rebetzke and Richards, 1999).

\section{Crop physiology: Stomatal conductance and chlorophyll content}

Closure of stomata reduces transpirational losses, thus minimising water losses through transpiration. Results of stomatal conductance (SC) were only collected during the 2011/12 planting season. The results showed highly significant differences $(P<0.001)$ between water regimes as well as significant differences $(P<0.05)$ between landraces (Fig. 2$)$. The trend showed that SC decreased with increasing water stress (Fig. 2). 'Red' and 'Brown' landraces showed the greatest decrease in response to water stress compared with the 'Light-brown' landrace (Fig. 2), demonstrating greater stomatal regulation in response to water stress. Stomatal closure is a plant's initial response to declining soil water content and has been characterised as a

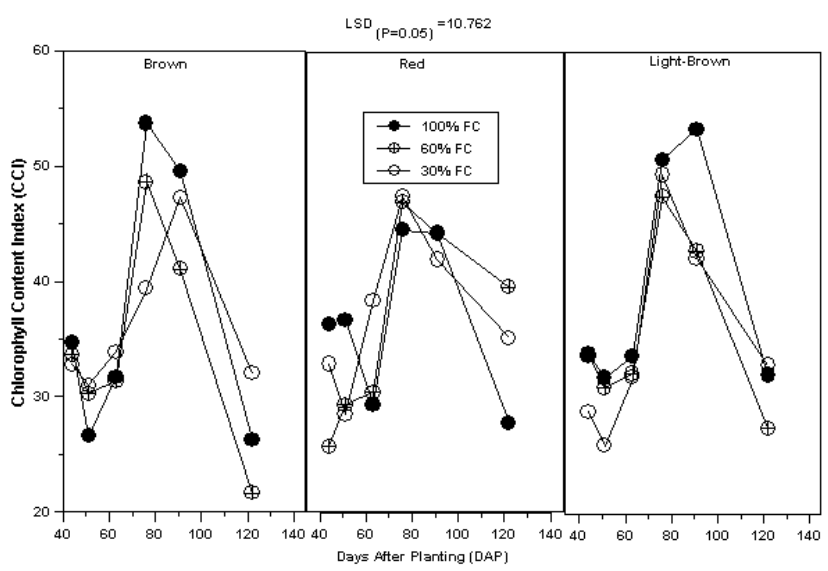

Figure 3

Chlorophyll content index (CCl) of bambara groundnut landraces ('Brown', 'Red' and 'Light brown') grown under a rain shelter during the 2011/12 planting season

drought avoidance mechanism (Farooq et al., 2009), as well as being a characteristic of increased water use efficiency under drought stress (Blum, 2005, 2009). It has previously been suggested as a component of bambara groundnut's drought resistance mechanism by Collinson et al. (1997). However, Blum $(2005,2009)$ argued that stomatal closure is a negative response to water stress in that it reduces $\mathrm{CO}_{2}$ availability leading to yield reduction under water stress.

Reduction in intracellular $\mathrm{CO}_{2}$, due to stomatal closure, results in reduced substrate availability for photosynthesis. Therefore, there is a need to down-regulate photosynthesis in line with reduced substrate availability. In this regard, chlorophyll content has been reported to decrease in water-stressed plants (Farooq et al., 2009), for example, in barley (Anjum et al., 2003) and sunflower (Kiani et al., 2008). Similar to SC, data for chlorophyll content index were only collected during the 2011/12 planting season. With respect to CCI, there were no significant differences $(P>0.05)$ between landraces, water regimes, or the interaction between these (Fig. 3), suggesting that chlorophyll content in bambara groundnut landraces was not as sensitive to water stress. Interestingly, with the exception of the 'Light-brown' landrace, 'Red' and 'Brown' had higher $\mathrm{CCI}$ at $30 \% \mathrm{ET}_{\mathrm{a}}$ relative to $60 \% \mathrm{ET}$, whilst all landraces had highest CCI at 100\% CCI (Fig. 3). These results once again showed the variability that exists within landraces, with respect to responses to water stress.

\section{Crop morphology}

Results of plant height and leaf number during 2010/11 and 2011/12 were variable (Figs. 4 and 5) with respect to differences between water regimes and landraces. During the 2011/12 season, the 'Light-brown' landrace performed better than the 'Brown' and 'Red' landraces, respectively. There was a trend, for both seasons, of decreasing plant height and leaf number in response to increasing water stress. The lowest values of plant height and leaf number were observed in the $30 \% \mathrm{ET}_{\mathrm{a}}$ treatment, followed by $60 \%$ and $100 \% \mathrm{ET}_{\mathrm{a}}$, respectively. The 'Red' landrace was shown to have the greatest decrease in plant height and leaf number under water stress compared with 'Light-brown' and 'Brown' (Figs. 4 and 5).

With respect to LAI, for both seasons, there were no differences $(P>0.05)$ between landraces, although the trend 


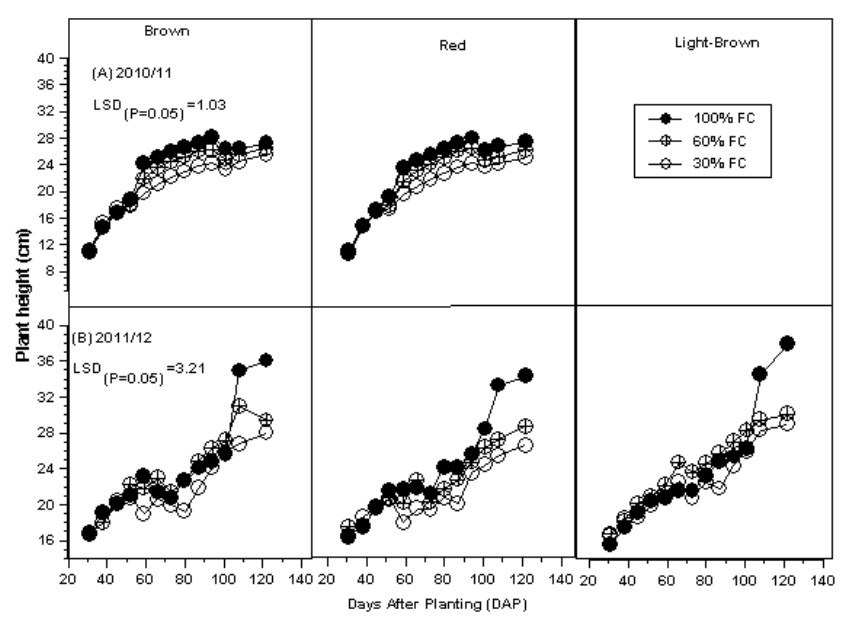

Figure 4

Plant height (cm) of bambara groundnut landraces ('Brown', 'Red' and 'Light brown') grown under a rain shelter during 2010/11 and 2011/12 planting seasons

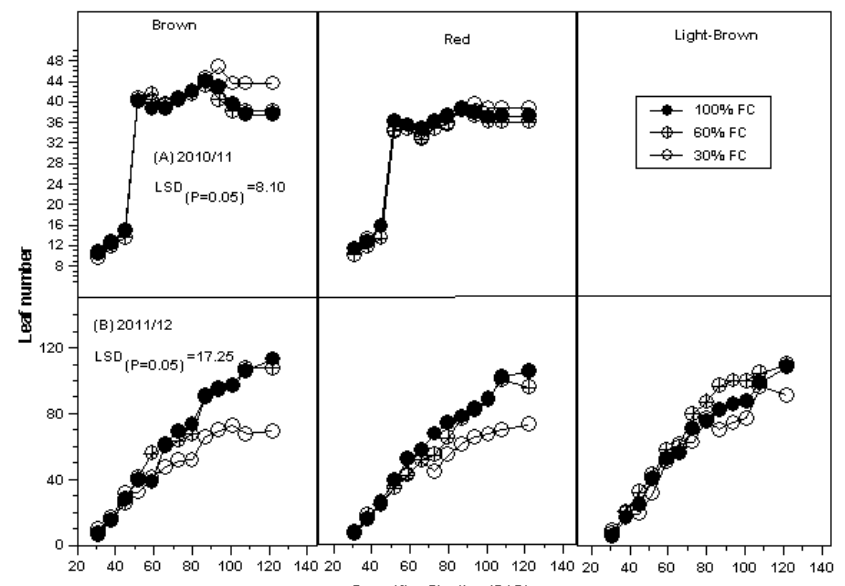

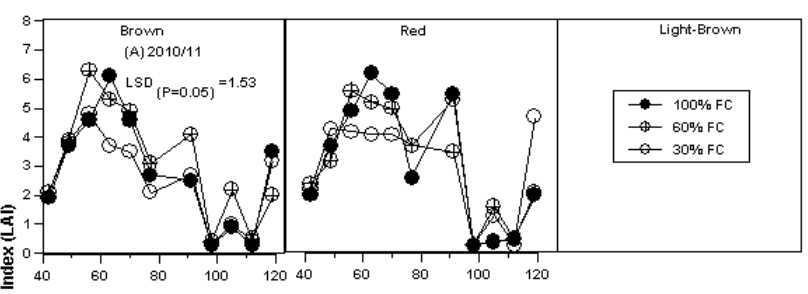

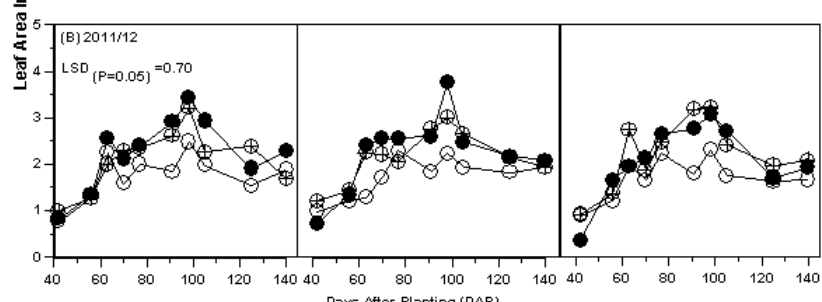

Figure 6

Leaf area index of bambara groundnut landraces ('Brown', 'Red' and 'Light brown') grown under a rain shelter during the 2010/11 and 2011/12 planting seasons

responsible for increased water use-efficiency, although this often occurs at the expense of yield potential (Blum, 2005).

\section{Crop phenology}

Results of crop phenology were observed during the 2011/12 planting season when all three landraces were planted. With the exception of time to flowering, all other phenological stages showed highly significant differences $(P<0.001)$ between water regimes but no differences $(P>0.05)$ between landraces (Table 1). For all phenological events observed, mean separation showed that $60 \%$ and $100 \%$ ETa were statistically similar, but significantly different from $30 \% \mathrm{ETa}$ (Table 1). Bambara groundnut landraces were shown to flower early, have a reduced flowering duration and mature early in
Figure 5

Leaf number of bambara groundnut landraces ('Brown', 'Red' and 'Light brown') grown under a rain shelter during 2010/11 and 2011/12 planting seasons

(2011/12) showed that 'Brown' and 'Red' performed better than 'Light-brown' (Fig. 6). For both seasons, results showed a decrease in LAI in response to increasing water stress; LAI was lowest at $30 \% \mathrm{ETa}$ compared with $60 \%$ and $100 \% \mathrm{ETa}$, respectively, which were statistically similar (Fig. 6). The reduction in LAI in response to water stress was assumed to be due to a corresponding reduction in plant height and leaf number (Figs. 4 and 5).

The growth responses of bambara groundnut to water stress have previously been described under field conditions using similar growth indices of plant height, leaf number and leaf area index (Collinson et al., 1996, 1997, 1999; Mwale et al., 2007; Vurayai et al., 2011a, 2011b; Mabhaudhi and Modi, 2013). There was consensus among the researchers that drought tolerance in bambara groundnut involved reduction in these growth indices. Reduced plant height, leaf number and LAI are mechanisms of reducing plant water use in response to decreasing soil water availability (Mitchell et al., 1998). Reduced canopy size is also
TABLE 1

Phenological stages of bambara groundnut landraces ('Brown', 'Red' and 'Light-brown') in response to 3 water regimes (30\%, $60 \%$ and $100 \% \mathrm{ET}_{3}$ ) during 2011/12 planting season

\begin{tabular}{|c|c|c|c|c|c|}
\hline \begin{tabular}{|l|} 
Water \\
Regime \\
$\left({ }^{\times} \mathrm{ETT}_{\mathrm{a}}\right)$ \\
\end{tabular} & Landrace & $\begin{array}{l}\text { Flowering } \\
\text { (DAP) }\end{array}$ & $\begin{array}{c}\text { Flowering } \\
\text { duration } \\
\text { (Days) }\end{array}$ & \begin{tabular}{|c|} 
Leaf \\
senescence \\
(DAP)
\end{tabular} & $\begin{array}{c}\text { Maturity } \\
\text { (DAP) }\end{array}$ \\
\hline \multirow{4}{*}{$30 \%$} & Brown & $61.00 \mathrm{ab}$ & $35.00 \mathrm{~d}$ & $96.0 \mathrm{~b}$ & $119.8 \mathrm{~b}$ \\
\hline & Red & $59.75 b$ & $42.00 \mathrm{~cd}$ & $101.8 \mathrm{~b}$ & $122.0 \mathrm{~b}$ \\
\hline & \begin{tabular}{|l|} 
Light-brown \\
\end{tabular} & $64.50 \mathrm{ab}$ & $48.75 \mathrm{abc}$ & $113.3 \mathrm{a}$ & $126.5 \mathrm{a}$ \\
\hline & Mean & $61.75^{\mathrm{b}}$ & $41.9^{b}$ & $103.7^{b}$ & $122.75^{b}$ \\
\hline \multirow{4}{*}{$60 \%$} & Brown & $65.25 \mathrm{ab}$ & $53.75 \mathrm{ab}$ & $119.0 \mathrm{a}$ & $128.0 \mathrm{a}$ \\
\hline & Red & $60.50 \mathrm{ab}$ & $58.50 \mathrm{a}$ & $119.0 \mathrm{a}$ & $128.0 \mathrm{a}$ \\
\hline & \begin{tabular}{|l|} 
Light-brown \\
\end{tabular} & $67.25 \mathrm{a}$ & $46.00 \mathrm{bc}$ & $113.2 \mathrm{a}$ & $126.5 \mathrm{a}$ \\
\hline & Mean & $64.33^{a}$ & $52.8^{\mathrm{a}}$ & $117.1^{\mathrm{a}}$ & $127.50^{\mathrm{a}}$ \\
\hline \multirow{4}{*}{$100 \%$} & Brown & $65.75 \mathrm{ab}$ & $53.25 \mathrm{ab}$ & $119.0 \mathrm{a}$ & $128.0 \mathrm{a}$ \\
\hline & Red & $65.25 \mathrm{ab}$ & $53.75 \mathrm{ab}$ & $119.0 \mathrm{a}$ & $128.0 \mathrm{a}$ \\
\hline & Light-brown & $64.50 \mathrm{ab}$ & $54.50 \mathrm{ab}$ & $119.0 \mathrm{a}$ & $128.0 \mathrm{a}$ \\
\hline & Mean & $65.75^{a}$ & $53.8^{\mathrm{a}}$ & $119.0^{\mathrm{a}}$ & $128.00^{a}$ \\
\hline \multicolumn{2}{|c|}{ LSD $_{(\mathrm{P}=0.05)}$ Water regime } & 3.73 & 5.72 & 5.52 & 1.74 \\
\hline \multicolumn{2}{|c|}{ LSD $_{(\mathrm{P}=0.05)}$ Landrace } & 3.73 & 5.72 & 5.52 & 1.74 \\
\hline \multicolumn{2}{|c|}{$\operatorname{LSD}_{(\mathrm{P}=0.05)}$ Water ${ }^{\star}$ Landrace } & 6.46 & 9.90 & 9.55 & 3.01 \\
\hline
\end{tabular}

${ }^{x} E T_{a}=$ crop water requirement. Values in the same column not sharing the same letter differ significantly at LSD $(P=0.05) . D A P=$ Days after planting. 


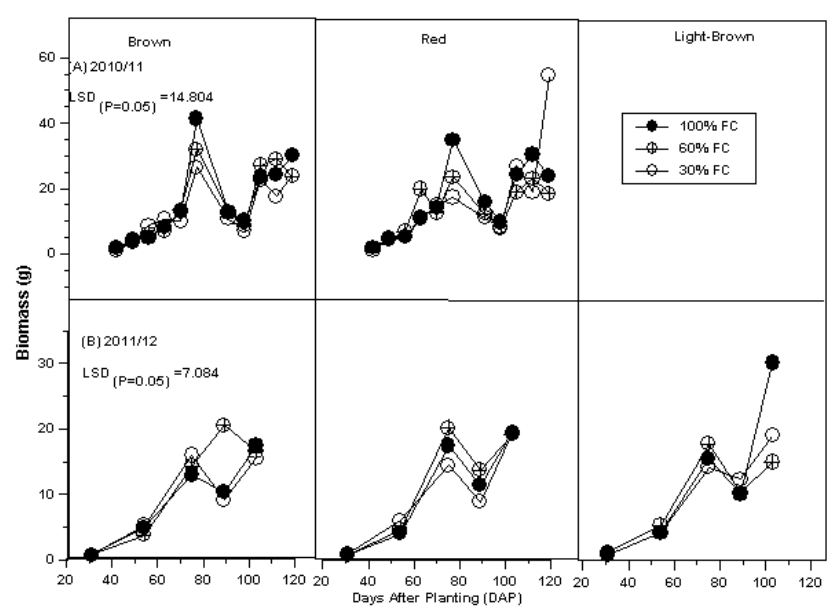

Figure 7

Biomass accumulation (per plant per dry matter basis) of bambara groundnut landraces ('Brown', 'Red' and 'Light brown') grown under a rain shelter during the 2010/11 and 2011/12 planting seasons

response to decreasing soil water availability (Table 1). Water stress reduced the vegetative stage of bambara groundnut; landraces flowered earlier at 30\% ETa compared with $60 \%$ and $100 \%$ ETa, respectively (Table 1 ).

Since bambara groundnut landraces took a long time to establish (Fig. 1), this effectively resulted in a shortened vegetative period which may also be linked to reduced plant height and leaf number under water-limited conditions (Figs. 4 and 5). In addition, water stress reduced the reproductive stage; decreased water availability resulted in shortened flowering duration or reproductive period at $30 \%$ ETa compared with $60 \%$ and $100 \%$ ETa, respectively (Table 1). Furthermore, water stress reduced the overall length of bambara groundnut landraces' crop cycle through early leaf senescence and subsequently early maturity (Table 1 ). With respect to landraces, 'Brown' and 'Red' landraces showed a consistent trend in flowering and maturing early in response to limited water availability compared with 'Light-brown'. However, 'Red' had a longer reproductive period compared with 'Brown' and 'Lightbrown', respectively; this was due to delayed leaf senescence in the 'Red' landrace (Table 1).

Early flowering, due to reduced vegetative growth (leaf number and area) is a major mechanism for moderating water loss under drought stress (Blum, 2005). According to Araus et al. (2002), early flowering in response to limited water availability, is a drought escape mechanism. This is equally true for reduced flowering duration, with the objective being to reproduce before water stress becomes terminal. Selection for high water use efficiency under limited water supply has tended to be biased towards plants that flower early and maintain a smaller canopy size (Blum, 2005, 2009). Hence, by definition, bambara groundnut landraces may be suitable for production under dryland conditions that require plants with a small canopy, moderated growth and short growth duration under water limited conditions.

\section{Biomass, yield and water use}

Biomass accumulation, over time, for both seasons, showed no significant differences $(P>0.05)$ between water regimes as well as between landraces (Fig. 7). However, closer inspection of results showed a trend of biomass decreasing with increasing water stress (Fig. 7); although there was variability between landraces. During 2010/11, this observation was clear at 112 DAP, which also corresponded with the vegetative peak of the plants (Fig. 7).

Crop yield during 2010/11 showed a clearer trend, with regards to differences between water regimes (Table 2). With the exception of final biomass, all other parameters measured showed highly significant differences $(P<0.001)$ between water regimes; there were no differences $(P>0.05)$ between the two landraces ('Brown' and 'Red') for all yield components. The results showed a trend of decline in HI, pod mass, pod number, biomass and grain yield in response to water stress. Correlations of the data showed that HI $(r=0.649)$, pod mass $(r=0.869)$ and pod number $(r=0.943)$ contributed significantly

\begin{tabular}{|c|c|c|c|c|c|c|c|}
\hline \multicolumn{8}{|c|}{$\begin{array}{c}\text { TABLE } 2 \\
\text { Yield components of bambara groundnut landraces ('Brown' and 'Red') in response } \\
\text { to } 3 \text { water regimes ( } 30 \%, 60 \% \text { and } 100 \% \mathrm{ET}) \text { during } 2010 / 11 \text { season }\end{array}$} \\
\hline $\begin{array}{l}\text { Water Regime } \\
\text { ('ET) }\end{array}$ & Landrace & $\begin{array}{l}\mathrm{HI}^{*} \\
\text { (\%) }\end{array}$ & $\begin{array}{c}\text { Pod } \\
\text { Mass (g) }\end{array}$ & $\begin{array}{l}\text { xPod No. } \\
\left.\text { (plant }^{-1}\right)\end{array}$ & $\begin{array}{c}\text { Biomass } \\
(\text { t.ha-1) }\end{array}$ & $\begin{array}{l}\text { Yield } \\
(\text { t.ha-1) }\end{array}$ & $\begin{array}{c}\text { y'WUE } \\
\left(\mathrm{kg}^{\left.-\mathrm{m}^{-3}\right)}\right.\end{array}$ \\
\hline \multirow{3}{*}{$30 \%$} & Brown & $10.55 c$ & $2.293 \mathrm{~b}$ & $2 \mathrm{~b}$ & $3.259 \mathrm{a}$ & $0.114 \mathrm{c}$ & $0.262 \mathrm{a}$ \\
\hline & Red & $15.04 \mathrm{bc}$ & $1.900 \mathrm{~b}$ & $3 \mathrm{~b}$ & $2.315 \mathrm{a}$ & $0.215 b c$ & $0.186 a$ \\
\hline & Mean & $12.80^{c}$ & $2.10^{c}$ & $3^{c}$ & $2.79^{b}$ & $0.16^{b}$ & $0.224^{\mathrm{a}}$ \\
\hline \multirow{3}{*}{$60 \%$} & Brown & $18.39 \mathrm{bc}$ & $3.893 \mathrm{~b}$ & $8 \mathrm{~b}$ & $4.176 \mathrm{a}$ & $1.078 \mathrm{bc}$ & $0.255 \mathrm{a}$ \\
\hline & Red & $14.65 \mathrm{bc}$ & $3.180 \mathrm{~b}$ & $7 \mathrm{~b}$ & $3.886 \mathrm{a}$ & $1.125 \mathrm{~b}$ & $0.237 \mathrm{a}$ \\
\hline & Mean & $16.50^{\mathrm{bc}}$ & $3.54^{\mathrm{b}}$ & $7^{b}$ & $4.03^{\mathrm{a}}$ & $1.10^{\mathrm{b}}$ & $0.246^{\mathrm{a}}$ \\
\hline \multirow{3}{*}{$100 \%$} & Brown & $51.83 a$ & $8.883 a$ & $17 \mathrm{a}$ & $3.062 \mathrm{a}$ & $2.701 \mathrm{a}$ & $0.139 \mathrm{a}$ \\
\hline & Red & $27.12 \mathrm{~b}$ & $7.712 \mathrm{a}$ & $15 \mathrm{a}$ & $5.011 \mathrm{a}$ & $2.486 \mathrm{a}$ & $0.233 a$ \\
\hline & Mean & $39.30^{\mathrm{a}}$ & $8.30^{\mathrm{a}}$ & $16^{a}$ & $4.04^{a}$ & $2.59^{a}$ & $0.186^{\mathrm{a}}$ \\
\hline \multicolumn{2}{|c|}{ Yield correlation $(r)$} & 0.295 & 0.649 & 0.869 & 0.943 & $\begin{array}{ll}----- \\
-1\end{array}$ & ------ \\
\hline \multicolumn{2}{|c|}{$\operatorname{LSD}_{(\mathrm{P}=0.05)}$ Water regime } & 10.48 & 1.946 & 4 & 1.906 & 0.652 & 0.116 \\
\hline \multicolumn{2}{|c|}{$\operatorname{LSD}_{(\mathrm{P}=0.05)}$ Landrace } & 8.55 & 1.589 & 4 & 1.556 & 0.533 & 0.095 \\
\hline \multicolumn{2}{|c|}{$\operatorname{LSD}_{(\mathrm{P}=0.05)}$ Land $^{*}$ Treat } & 14.82 & 2.752 & 6 & 2.696 & 0.923 & 0.164 \\
\hline
\end{tabular}

${ }^{x} E T_{a}=$ crop water requirement. ${ }^{*} H I=$ harvest index; ${ }^{x}$ Pod number values were rounded off to the nearest integer since pod number represents discrete data; ${ }^{y} W U E=$ water use efficiency. Values in the same column not sharing the same letter differ significantly at $L S D(P=0.05)$. 


\begin{tabular}{|c|c|c|c|c|c|c|c|}
\hline \multicolumn{8}{|c|}{$\begin{array}{l}\text { TABLE } 3 \\
\text { Yield components of bambara groundnut landraces ('Brown', 'Red' and ‘Light-brown') in } \\
\left.\text { response to } 3 \text { water regimes ( } 30 \%, 60 \% \text { and } 100 \% \mathrm{ET}_{a}\right) \text { during } 2011 / 12 \text { planting season }\end{array}$} \\
\hline $\begin{array}{l}\text { Water Regime } \\
\left({ }^{\times} E T_{a}\right)\end{array}$ & Landrace & $\begin{array}{l}\mathrm{HI}^{*} \\
(\%)\end{array}$ & $\begin{array}{l}\text { Pod Mass } \\
\text { (g) }\end{array}$ & $\begin{array}{l}\text { xpod No. } \\
\text { (plant }{ }^{-1} \text { ) }\end{array}$ & $\begin{array}{c}\text { Biomass } \\
\left(\mathrm{t} \cdot \mathrm{ha}^{-1}\right)\end{array}$ & $\begin{array}{l}\text { Yield } \\
\left(\mathrm{t} \cdot \mathrm{ha}^{-1}\right)\end{array}$ & $\begin{array}{c}\text { yWUE } \\
\left(\mathrm{kg} \cdot \mathrm{m}^{-3}\right)\end{array}$ \\
\hline \multirow{4}{*}{$30 \%$} & Brown & $15.7 \mathrm{a}$ & $4.914 \mathrm{bc}$ & $7 \mathrm{ab}$ & $5.414 \mathrm{c}$ & $0.362 \mathrm{~b}$ & $0.114 \mathrm{ab}$ \\
\hline & Red & $12.26 \mathrm{ab}$ & $5.361 \mathrm{bc}$ & $8 \mathrm{ab}$ & $7.414 \mathrm{bc}$ & $0.348 \mathrm{~b}$ & $0.144 \mathrm{a}$ \\
\hline & \begin{tabular}{|l|} 
Light-brown \\
\end{tabular} & $14.39 \mathrm{ab}$ & $6.446 \mathrm{bc}$ & $10 \mathrm{ab}$ & $7.856 \mathrm{abc}$ & $0.652 \mathrm{ab}$ & $0.093 b$ \\
\hline & Mean & $14.02^{\mathrm{a}}$ & $5.57^{\mathrm{a}}$ & $8.46^{\mathrm{a}}$ & $6.91^{\mathrm{b}}$ & $0.45^{\mathrm{a}}$ & $0.120^{a}$ \\
\hline \multirow{4}{*}{$60 \%$} & Brown & $12.30 \mathrm{ab}$ & $6.015 \mathrm{bc}$ & $8 \mathrm{ab}$ & $8.550 \mathrm{abc}$ & $0.623 \mathrm{ab}$ & $0.096 \mathrm{~b}$ \\
\hline & Red & $11.63 \mathrm{ab}$ & $6.084 \mathrm{bc}$ & $8 \mathrm{ab}$ & $8.612 \mathrm{abc}$ & $0.319 \mathrm{~b}$ & $0.118 \mathrm{ab}$ \\
\hline & Light-brown & $15.34 \mathrm{ab}$ & $8.761 \mathrm{ab}$ & $11 \mathrm{ab}$ & $9.468 \mathrm{ab}$ & $0.712 \mathrm{ab}$ & $0.129 \mathrm{ab}$ \\
\hline & Mean & $13.09^{a}$ & $6.95^{\mathrm{a}}$ & $9.02^{\mathrm{a}}$ & $8.88^{\mathrm{ab}}$ & $0.55^{\mathrm{a}}$ & $0.110^{\mathrm{ab}}$ \\
\hline \multirow{4}{*}{$100 \%$} & Brown & $7.82 \mathrm{~b}$ & $4.214 \mathrm{c}$ & $5 \mathrm{ab}$ & $8.757 \mathrm{abc}$ & $0.419 \mathrm{~b}$ & $0.110 \mathrm{ab}$ \\
\hline & Red & 9.81ab & $4.549 \mathrm{bc}$ & $7 \mathrm{ab}$ & $8.107 \mathrm{abc}$ & $0.518 \mathrm{~b}$ & $0.097 \mathrm{~b}$ \\
\hline & \begin{tabular}{|l|} 
Light-brown \\
\end{tabular} & $15.99 a$ & $10.699 \mathrm{a}$ & $13 a$ & $11.054 \mathrm{a}$ & $1.013 \mathrm{a}$ & $0.107 \mathrm{ab}$ \\
\hline & Mean & $11.21^{\mathrm{a}}$ & $6.49^{a}$ & $8.49^{a}$ & $9.31^{\mathrm{a}}$ & $0.65^{\mathrm{a}}$ & $0.100^{\mathrm{b}}$ \\
\hline \multicolumn{2}{|c|}{ Yield correlation (r) } & 0.541 & 0.592 & 0.853 & 0.697 & ----- & ----- \\
\hline \multicolumn{2}{|c|}{$\mathrm{LSD}_{(\mathrm{P}=0.05)}$ Water regime } & 3.938 & 2.188 & 3.645 & 1.715 & 0.214 & 0.021 \\
\hline \multicolumn{2}{|c|}{$\mathrm{LSD}_{(\mathrm{P}=0.05)}$ Landrace } & 3.938 & 2.188 & 3.645 & 1.715 & 0.214 & 0.021 \\
\hline \multicolumn{2}{|c|}{$\mathrm{LSD}_{(\mathrm{P}=0.05)}$ Land $^{\star W}$ Water } & 6.821 & 3.790 & 6.313 & 2.970 & 0.370 & 0.037 \\
\hline
\end{tabular}

${ }^{x} E T=$ crop water requirement. ${ }^{*} H I=$ harvest index; ${ }^{x}$ Pod number values were rounded off to the nearest integer since pod number represents discrete data; ${ }^{y} W U E=$ water use efficiency. Values in the same column not sharing the same letter differ significantly at LSD $(P=0.05)$.

to yield. Consequently, reduction in yield under stress was due to decreased HI, pod mass and number (Table 2).

Yield results from 2011/12 were contrary to the trend observed during 2010/11 (Table 3). With the exception of biomass, all other yield components showed no differences $(P>0.05)$ between landraces and water regimes; there was also no clear trend in response to water stress. Only final biomass was significantly $(P<0.05)$ affected by water stress, with biomass decreasing in response to $60 \% \mathrm{ETa}$ and $30 \% \mathrm{ETa}$, respectively (Table 3 ). Yields achieved during the 2011/12 planting season were also significantly lower than yields achieved in the previous season. Although correlations showed a similar trend as in the previous season, they were lower than those reported for 2010/11, suggesting overall poor crop performance during 2011/12.

Results of yield, for both planting seasons, showed that pod yield (pod number and mass) was the greatest influence on seed mass or yield. Even though bambara groundnut has been reported to be drought tolerant, water stress was still able to affect yield. These results are similar to other studies in the literature (Babiker, 1989; Berchie et al., 2010; Berchie et al., 2012; Mabhaudhi and Modi, 2013), which all reported reduced seed yield in bambara groundnut landraces in response to limited water availability under field conditions. In this study, reduced seed yield, through reduced pod mass and number, may be related to a shorter flowering duration, which limited pod number, while low pod mass may be linked to earlier senescence which affected pod filling. This was also observed in the number of empty pods. However, what is noteworthy is bambara groundnut's ability to still produce yield even under severe water stress (30\% ETa). According to Berchie et al. (2012), this confirms bambara groundnut's resilience under drought stress and further justifies the need for more research on the crop, with a view to promoting it as a food security crop.
Results of water use efficiency (WUE) showed no (significant) differences $(P>0.05)$ between water regimes as well as between landraces for both planting seasons (Tables 2 and 3). During the 2010/11 planting season, WUE was highest at $60 \%$ and $30 \% \mathrm{ETa}$, respectively, compared with $100 \% \mathrm{ETa}$, suggesting that WUE increased in response to limited water availability. The lack of clear differences between treatments during 2010/11 was due to the numerator - biomass, which also showed a trend of no differences between treatments (Table 2). However, during the $2011 / 12$ planting season, the observed trend showed WUE increasing with decreasing water availability. Water use efficiency was highest in the 30\% ETa treatment, followed by $60 \%$ and $100 \%$, respectively; mean separation showed that WUE at 30\% ETa was significantly higher than at $100 \%$ ETa but similar to the $60 \%$ ETa water regime. This was in line with the trend observed for final biomass during the 2011/12 season (Table 3), suggesting that WUE was more influenced by biomass than water use.

High water use efficiency under limited water conditions is linked to reduced canopy size (plant height, leaf number, LAI), reduced transpirational losses (low stomatal conductance) as well as a shortened growth duration (Blum, 2005, 2009). While reduced canopy size and stomatal closure directly moderate water losses by the crop, reduced crop duration effectively reduces the amount of water applied to the crop. As such, in line with observed reductions in canopy size, stomatal conductance and crop duration, WUE increased in response to declining water availability. Our results for WUE, although slightly higher, were similar to those reported in a long-running project on bambara groundnut (BAMFOOD), where it was found that bambara groundnut's WUE is about $2.1 \mathrm{~g} \cdot \mathrm{mm}^{-1} \cdot \mathrm{m}^{-2}$, a value comparable to that of other legumes (Azam-Ali et al., 2004). However, as argued by Blum $(2005,2009)$, increased WUE often occurs at the expense of yield potential. 


\section{CONCLUSIONS}

This study showed that bambara groundnut landraces have some resilience to reduced water availability. Increased water use efficiency in bambara groundnut landraces in response to water stress was achieved through canopy size and crop duration adjustments. Limited water availability resulted in reduction in growth indices of plant height, leaf number and leaf area index, thus minimising water losses. In addition, bambara groundnut landraces were shown to respond to limited water availability through closure of stomata, thus reducing transpirational losses. Furthermore, imposition of stress resulted in early flowering, reduced flowering duration, early senescence and, ultimately, early maturity. These responses are characteristic of drought avoidance and escape mechanisms. Water stress was shown to reduce seed yield through reduced pod number and mass, although bambara groundnut landraces were shown to be still productive under limited water conditions. While bambara groundnut landraces showed growth and phenological responses to water stress, slow establishment in bambara groundnut landraces may result in water losses through soil evaporation during the establishment stage. Lastly, although there was much variability between 'Brown', 'Light-brown' and 'Red' landraces, the trend showed that the darker colours were more consistent in their responses to water stress.

\section{ACKNOWLEDGEMENTS}

The Water Research Commission of South Africa is acknowledged for funding through WRC Project No. K5/1771/4 'WaterUse of Drought Tolerant Crops' (WRC, 2009).

\section{REFERENCES}

ANJUM F, YASEEN M, RASUL E, WAHID A and ANJUM S (2003) Water stress in barley (Hordeum vulgare L.). II. Effect on chemical compositions and chlorophyll contents. Pak. J. Agric. Sci. 40 45-49.

ARAUS JL, SLAFER GA, REYNOLDS MP and ROYO C (2002) Plant breeding and drought in C3 cereals: what should we breed for? Ann. Bot. 89 925-940.

AYKROYD WR and DOUGHTY J (1982) Legumes in Human Nutrition. FAO Food and Nutrition Paper 20. FAO, Rome.

AZAM-ALI SN, SESAY A, KARIKARI S, MASSAWE FJ, AGUILARMANJARREZ J, BANNAYAN M and HAMPSON KJ (2001) Assessing the potential of an underutilized crop - a case study using bambara groundnut. Explor. Agric. 37 433-472.

AZAM-ALI SN, KHONGA E, WENZEL G, FLESSNER K and SESAY A (2004) Increasing the productivity of bambara groundnut (Vigna subterranea (L.) Verdc.) for sustainable food production in semi-arid Africa. BAMFOOD Project Final Report. URL: http:// ebookbrowse.com/bamfood-final-report-pdf-d38034097 (Accessed 8 May 2012).

BABIKER AMA (1989) Growth, dry matter and yield of bambara groundnut (Vigna subterranea) and groundnut (Arachis hypogaea) under irrigated and droughted conditions. MSc Thesis, University of Nottingham, UK.

BERCHIE JN, SARKODIE-ADDO J, ADU-DAPAAH H, AGYEMANG A, ADDY S, ASARE E and DONKOR J (2010) Yield evaluation of three early maturing bambara groundnut (Vigna subterranea L. Verdc) landraces at the CSIR-Crops Research Institute, FumesuaKumasi, Ghana. J. Agron. 9 175-179.

BERCHIE JN, OPOKU M, ADU-DAPAAH H, AGYEMANG A, SARKODIE-ADDO J, ASARE E, ADDO J and AKUFFO H (2012) Evaluation of five bambara groundnut (Vigna subterranea L. Verdc) landraces to heat and drought stress at Tono-Navrongo, Upper East Region of Ghana. Afr. J. Agric. Res. 7 250-256.
BLUM A (2005) Drought resistance, water-use efficiency, and yield potential - are they compatible, dissonant, or mutually exclusive? Aust. J. Agric. Res. 56 1159-1168.

BLUM A (2009) Effective use of water (EUW) and not water-use efficiency (WUE) is the target of crop yield improvement under drought stress. Field Crops Res. 112 119-123.

CAMBELL GS and MULLA DJ (1990) Measurement of soil water content and potential. In: Stewart BA and Nielsen DR (eds) Irrigation of Agricultural Crops. Agronomy 30 127-142.

COLLINSON ST, AZAM-ALI SN, CHAVULA KM and HODSON DA (1996) Growth development and yield of bambara groundnut (Vigna subterranea) in response to soil moisture. J. Agric. Sci. 126 307-318.

COLLINSON ST, BERCHIE J and AZAM-ALI SN (1999) The effect of soil moisture on light interception and the conversion coefficient for three landraces of bambara groundnut (Vigna subterranea). J. Agric. Sci. 133 151-157.

COLLINSON ST, CLAWSON EJ, AZAM-ALI SN and BLACK CR (1997) Effects of soil moisture deficits on the water relations of bambara groundnut (Vigna subterranea L. Verdc.). J. Expt. Bot. 48 877-884

DWAF (DEPARTMENT OF WATER AFFAIRS AND FORESTRY, SOUTH AFRICA) (2004) National Water Resource Strategy ( $1^{\text {st }}$ edn.). Department of Water Affairs and Forestry, Pretoria.

FAO (2001) A Global Mapping System for Bambara Groundnut Production. FAO, Rome.

FAROOQ M, WAHID A, KOBAYASHI N, FUJITA D and BASRA SMA (2009) Plant drought stress: effects, mechanisms and management. Agron. Sustain. Dev. 29 185-212.

FRENCH RJ and SCHULTZ JE (1984) Water use efficiency of wheat in a Mediterranean-type environment. I. The relation between water use and climate. Aust. J. Agric. Res. 35 743-764.

HASSAN R (2006) Climate Change and African Agriculture. Policy No. 28. Based on Durand (2006) Assessing the impact of climate change on crop water use in South Africa. CEEPA Discussion Paper No. 28, CEEPA, University of Pretoria.

IWMI (INTERNATIONAL WATER MANAGEMENT INSTITUTE) (1996) World Water Demand and Supply, 1990 to 2025: Scenarios and Issues. Research Report 19. International Water Management Institute, Battaramulla, Sri Lanka.

KIANI SP, MAURY P, SARRAFI A and GRIEU P (2008) QTL analysis of chlorophyll fluorescence parameters in sunflower (Helianthus annus L.) under well-watered and water-stressed conditions. Plant Sci. 175 565-573.

LAKER MC (2007) Introduction to the special issue of Water SA on indigenous crops, water and human nutrition. Water SA 33 311-315.

LINNEMANN AR and AZAM-ALI SN (1993) Bambara groundnut (Vigna subterranea L. Verdc). In: Williams JT (ed.) Underutilised Crops Series. II. Vegetable and Pulses. Chapman and Hall, London, UK. 13-58.

MABHAUDHI T and MODI AT (2013) Growth, phenological and yield responses of a bambara groundnut (Vigna subterranea L. Verdc) landrace to imposed water stress: I. Field conditions. S.Afr. J. Plant Soil 30 (2) (in press).

MABHAUDHI T and MODI AT (2011) Can hydro-priming improve germination vigour, speed and emergence of maize landraces under water stress? J. Agric. Sci. Technol. B $120-28$.

MABHAUDHI T and MODI AT (2010) Early establishment performance of local and hybrid maize under two water stress regimes. S. Afr. J. Plant Soil 27 (4) 299-304.

MBATHA TP and MODI AT (2010) Response of local mustard germplasm to water stress. S. Afr. J. Plant Soil 27 (4) 328-330.

MITCHELL JH, SIAMHAN D, WAMALA MH, RISIMERI JB, CHINYAMAKOBVU E, HENDERSON SA and FUKAI S (1998) The use of seedling leaf death scores for evaluation of drought resistance of rice. Field Crops Res. 55 129-139.

MUKURUMBIRA LW (1985) Effects of the rate of fertiliser nitrogen and the previous grain legume on maize yields. Zimbabwe Agric. J. 82 177-179.

MWALE SS, AZAM-ALI SN and MASSAWE FJ (2007) Growth and development of bambara groundnut (Vigna subterranea) 
in response to soil moisture I. Dry matter and yield. Eur. J. Agron. $26345-353$.

REBETZKE GJ and RICHARDS RA (1999) Genetic improvement of early vigour in wheat. Aust. J. Agric. Res. 50 291-301.

REPUBLIC OF SOUTH AFRICA (1998) National Water Act (Act No. 36 of 1998). Government Gazette No. 19182

SESAY A, MPUISANG T, MORAKE TS, AL-SHAREEF I, CHIPETE HJ and MOSEKI B (2010) Preliminary assessment of bambara groundnut (Vigna subterranea L.) landraces for temperature and water stress tolerance under field conditions in Botswana. S. Afr. J. Plant Soil 27 312-321.

SIDDIQUE KHM, TENNANT D, PERRY MW and BELFORD RK (1990) Water use and water use efficiency of old and modern wheat cultivars in a Mediterranean-type environment. Aust. J. Agric. Res. 41 431-447.

SINEFU F (2011) Bambara groundnut response to controlled environment and planting date associated water stress. MSc thesis, University of KwaZulu-Natal, Pietermaritzburg, South Africa.
SWANEVELDER CJ (1998) Bambara - food for Africa. National Department of Agriculture, South Africa. Government Printer, Republic of South Africa.

VURAYAI R, EMONGOR V and MOSEKI B (2011a) Physiological responses of Bambara Groundnut (Vigna subterranea L. Verdc) to short periods of water stress during different developmental stages. Asian J. Agric. Sci. 3 (1) 37-43.

VURAYAI R, EMONGOR V and MOSEKI B (2011b) Effect of water stress imposed at different growth and development stages on morphological traits and yield of Bambara Groundnut (Vigna subterranea L. Verdc). Am. J. Plant Physiol. 6 (1) 17-27.

WRC (WATER RESEARCH COMMISSION, SOUTH AFRICA) (2009) WRC Knowledge Review 2008/09. Water Research Commission, Pretoria.

ZULU NS and MODI AT (2010) A preliminary study to determine water stress tolerance in wild melon (Citrillus lanatus L.). S. Afr. J. Plant Soil 27 334-336. 